\title{
Perceptions of Higher Specialist Trainees and Fellows of the Proposed Sláintecare Consultant Contract and Implications for Workforce Planning in Ireland
}

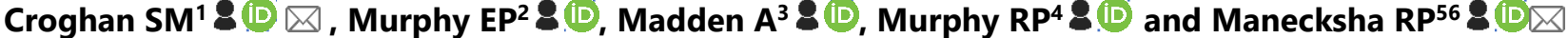 \\ ${ }^{1}$ Higher Surgical Training, Urology, Royal College of Surgeons in Ireland \\ ${ }^{2}$ Higher Surgical Training, Trauma and Orthopaedics, Royal College of Surgeons in Ireland \\ ${ }^{3}$ Higher Surgical Training, Urology, Royal College of Surgeons in Ireland \\ ${ }^{4}$ Higher Medical Training, Geriatric and General Internal Medicine, Royal College of Physicians of Ireland \\ ${ }^{5}$ National Training Programme Director for Urology, Royal College of Surgeons in Ireland \\ ${ }^{6}$ Clinical Associate Professor, Department of Surgery, Trinity College Dublin, Ireland
}

$\triangle$ Corresponding Authors: Prof Rustom Manecksha - rmanecksha@rcsi.ie and Stefanie Croghan stefaniecroghan@rcsi.ie

\section{ARTICLE INFORMATION}

Volume: 2

Issue: 2

DOI: 10.32996/jmhs.2021.2.2.5

\section{KEYWORDS}

Workforce planning; consultant contract; Sláintecare; doctor recruitment; doctor emigration; doctor retention; trainee perceptions; training in Ireland; trainee survey; training concerns

\section{ABSTRACT}

The aim of this study was to explore the perceptions of higher specialist trainees and fellows in Ireland with respect to the Irish Department of Health's recent proposal to implement a drafted, non-negotiated, consultant contract under a new model for healthcare, termed the Sláintecare plan. A customized survey, incorporating multiplechoice and Likert-scale questions and a free-text option, was disseminated to doctors enrolled in Irish higher specialist training (HST) programmes and pre-consultant HST graduates (fellows). Responses were compiled and analysed. There were a total of 1109 respondents across all specialities. Trainees were particularly concerned regarding the Sláintecare contract's potential impact on their abilities to engage in patient advocacy and provide optimal patient care in the future, the maintenance of specialist skillsets, their ownership of intellectual property and a stable location of the practice. Of respondents, 93.7\% (1003/1070) indicated that they would consider working abroad rather than accept the proposed contract. This study highlights the perceptions and concerns of the higher specialist trainees and fellows of Ireland. A large proportion may emigrate rather than accept the Sláintecare proposals. Concerns exist surrounding the ability to advocate for patients, to provide patient care, the proposed working conditions and perceived potential to deskill under this contract's terms.

\section{Introduction}

There has been attention focused upon the Irish Department of Health's recent declaration of intention to implement a new nonnegotiated contract for consultant doctors under a new model for healthcare, termed Sláintecare.

There has been anecdotal concern amongst trainees that the stated aims of the proposed Sláintecare contract (hereafter referred to as 'the contract') may not be aligned with clinicians' ability to deliver safe and effective patient care under the proposed working conditions.

This survey aimed to assess the perceptions and concerns of higher specialist trainee registrars (SpRs) and fellows trained in Ireland with respect to the proposed contract. SpRs and fellows were selected in order to be able to focus upon themes that would be pressing to those expected to be appointed to consultant posts in the near future.

\section{Background and Literature Review}

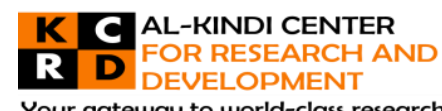

Your gateway to world-class research

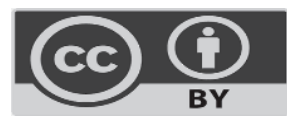

Published by Al-Kindi Center for Research and Development, United Kingdom. Copyright (c) the author(s). This open access article is distributed under a Creative Commons Attribution (CC-BY) 4.0 license 
The proposed Sláintecare contract aims to deliver 'a safe, quality health and social care service that meets the needs of our growing population'. It also aims to 'attract and train the best healthcare clinicians, managers, and staff' (Department of Health, 2021a, 2021b). This is on a background of a "consensus in Ireland that the health system is underperforming and that a fundamental transformation is needed to make it fit to meet future demands"(OECD, 2019 ), and significant concerns regarding large-scale doctor emigration (Humphries, Creese, Byrne, \& Connell, 2021).

\section{Methodology}

A custom-designed survey exploring perceptions of the proposed contract and its implications on career-planning was disseminated to trainees across specialities recognised by the Training Colleges of Ireland. The survey was designed independently of representative groups or unions. Trainees were eligible to participate if they were enrolled in a higher specialist training (HST) post as a specialist registrar (SpR) or completed specialist training and undertook a pre-consultancy fellowship. Current or retired consultants were excluded. Participants were surveyed using an electronic platform, with questionnaires disseminated via identified speciality representatives. A deadline for survey completion was set at five days from dissemination.

The demographics of the population were collected. This included a year in training and the speciality of the training post. The number of current trainees in higher specialist training posts was accessed using the Irish Health Service Executive (HSE) workforce report 2020-2021 (Health Service Executive, 2021).

The survey used a combination of multiple-choice and Likert-scale questions to quantify satisfaction or concern with various aspects of the proposed contract. A free-text box was provided for trainees to register any additional concerns with respect to the proposed contract. Questionnaire free-text responses were compiled and interpreted using qualitative research methodology. Thematic analysis was applied using an inductive approach. NVivo ${ }^{\circledR}$ software (QSR International Pty Ltd. Version 12) was used to code and group data.

\section{Results}

There were 1109 survey responses received. The HSE Workforce Report in 2020-2021 states that there are 1602 higher specialist training posts for the broad disciplines of Medicine, Surgery, Paediatrics, Radiology, Anaesthesiology and Emergency Medicine tabulated below (Health Service Executive, 2021). This number does not include trainees in General Practice. General practice trainees were not surveyed, as general practitioners work under a different contract type. The demographics of the respondents are represented in Table 1.

There were 623 (56.2 \%) first to third-year SpRs, 349 (31.5\%) fourth to sixth-year SpRs and 125 (11.3\%) post-CCT (certificate of completion of training) respondents, with 12 unclassified respondents. The vast majority $(95.3 \%)$ stated that they had read the contract in full.

\begin{tabular}{|c|c|c|c|}
\hline SPECIALITY & COMPRISING & RESPONDENTS (N)* & $\begin{array}{l}\text { NUMBER OF } \\
\text { HIGHER SPECIALIST } \\
\text { TRAINEES IN } \\
\text { SPECIALITY^ }\end{array}$ \\
\hline Anaesthesiology & Anaesthesiology \& Intensive Care & 162 & 155 \\
\hline $\begin{array}{l}\text { Emergency } \\
\text { Medicine }\end{array}$ & Emergency Medicine & 59 & 61 \\
\hline Medicine & $\begin{array}{l}\text { Cardiology, Dermatology, Endocrinology, } \\
\text { Gastroenterology, Geriatric } \text { Medicine, } \\
\text { Infectious Diseases, Medical Oncology, } \\
\text { Nephrology, Neurology, Palliative } \\
\text { Medicine, Respiratory Medicine, } \\
\text { Rheumatology }\end{array}$ & 280 & 441 \\
\hline Ophthalmology & Surgical \& Medical Ophthalmology & 13 & 23 \\
\hline
\end{tabular}


reported they would consider working abroad rather than in Ireland, should the proposed Sláintecare consultant contract be implemented (Figure 2).

Nine hundred and four respondents (84.7\%) stated that they would consider adopting full-time private practice in Ireland rather than accept the proposed Sláintecare contract.

\subsection{Free-Text Responses}

Unstructured free-text responses were provided by 526 respondents. Qualitative analysis of this data revealed multiple recurrent themes. This is included in Appendix 1. A brief summary of grouped themes is presented in Table 2.

\section{Figure 1.}

Responses

regarding

concerns

surrounding

patient care,

advocacy and

working

patterns

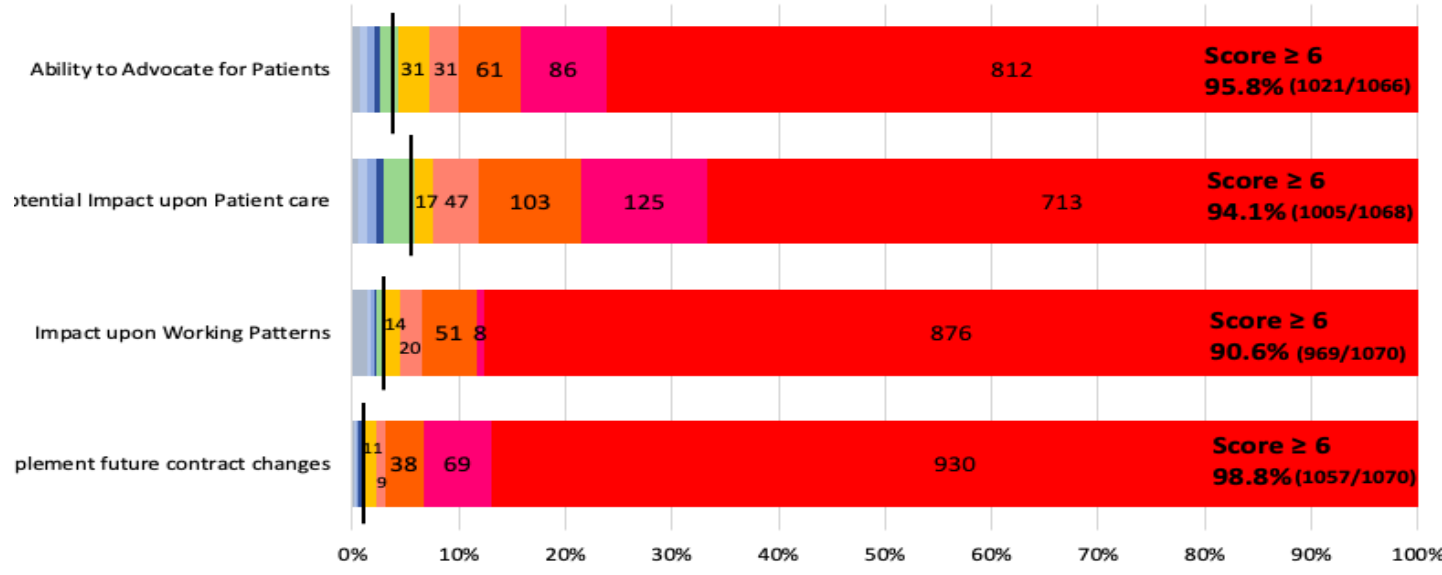

Figure 2.

Concerns

regarding

deskilling and

working

abroad

Consider working abroad instead of Ireland

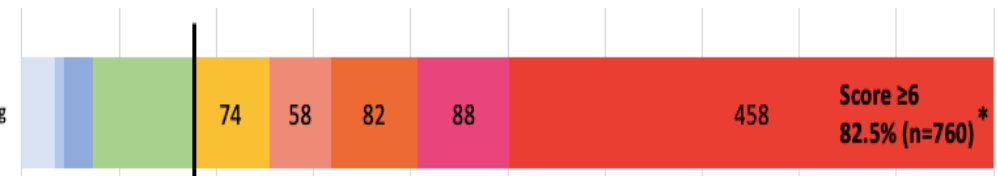

Concerned about deskilling

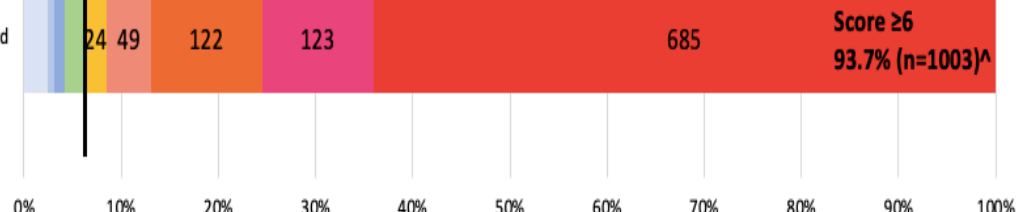

- Applies to procedural specialities; respondents $n=921$

- ^Denominator $n=1070$

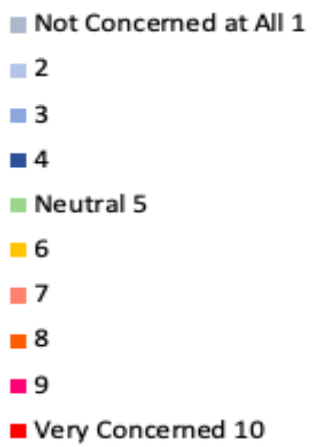




\begin{tabular}{|c|c|c|c|}
\hline Theme & Examples Cited & Theme & Examples Cited \\
\hline $\begin{array}{c}\text { Patient } \\
\text { Advocacy/Censorship }\end{array}$ & $\begin{array}{l}\text { - Stated terms interpreted as "a } \\
\text { gagging order," "tantamount to } \\
\text { censorship," and removing the } \\
\text { ability "to whistleblow." } \\
\text { - Seen as potentially "unethical } \\
\text { for any medical professional to } \\
\text { sign a contract that so severely } \\
\text { curtails their ability to advocate } \\
\text { for patients." }\end{array}$ & $\begin{array}{c}\text { Loss of } \\
\text { Specialist Skillsets }\end{array}$ & $\begin{array}{l}\text { - Potential reduction or loss of } \\
\text { specialist skills under terms of the } \\
\text { Sláintecare contract, due to "very } \\
\text { poor access" to "theatre time and } \\
\text { elective beds," available "within } \\
\text { the public sector." } \\
\text { - Desire stated to undertake } \\
\text { additional private practice to } \\
\text { "maintain surgical skills," and } \\
\text { patient outcomes - "busiest } \\
\text { surgeons are the best [surgeons]." } \\
\text { - May result in disinclination to } \\
\text { obtain complex skillsets on } \\
\text { fellowship and trainee-consultant } \\
\text { "direct competition" for cases. } \\
\text { - A potential future in which } \\
\text { "standard procedures cannot be } \\
\text { safely offered by entire hospitals" } \\
\text { was starkly predicted. }\end{array}$ \\
\hline $\begin{array}{c}\text { Ownership of } \\
\text { Intellectual Property }\end{array}$ & $\begin{array}{l}\text { - "Very serious concerns" } \\
\text { regarding employer's } \\
\text { "ownership" of a consultant's } \\
\text { intellectual property, including } \\
\text { that created outside of working } \\
\text { hours and the work premises. } \\
\text { - Seen as "Orwellian," } \\
\text { approaching "outright theft," } \\
\text { and predicted to "reduce } \\
\text { innovation amongst } \\
\text { consultants." }\end{array}$ & $\begin{array}{l}\text { Desire for Job } \\
\text { Stability and } \\
\text { Geographical } \\
\text { Permanence }\end{array}$ & $\begin{array}{l}\text { - Concept of "geographic } \\
\text { impermanence" with consultants } \\
\text { having "no control" over potential } \\
\text { redeployment viewed as } \\
\text { "unacceptable." } \\
\text { - The "incredible difficulty" of } \\
\text { "moving around the } \\
\text { country/abroad to train," a feature } \\
\text { of most Irish postgraduate } \\
\text { training schemes, sometimes } \\
\text { performed "for a decade," as often } \\
\text { as "every } 6 \text { months," and "with } \\
\text { young children" "dragged along," } \\
\text { emphasised. } \\
\text { - Tangible "craving" for "stability" } \\
\text { and "security" with ability to } \\
\text { "finally" obtain "a mortgage" and } \\
\text { "build a life," without fear of } \\
\text { "further upheaval." }\end{array}$ \\
\hline $\begin{array}{cc}\text { Incompatibility } & \text { with } \\
\text { Research } & \text { and } \\
\text { Academia } & \end{array}$ & 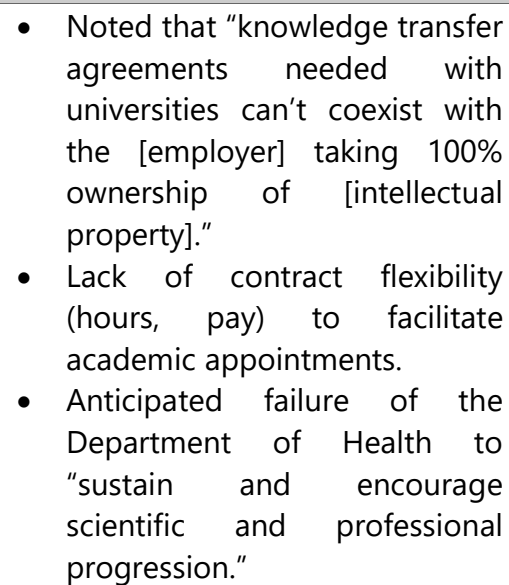 & $\begin{array}{l}\text { Incompatibility } \\
\text { with Family Life }\end{array}$ & $\begin{array}{l}\text { - Concerns regarding relocation } \\
\text { and a potential shift work pattern } \\
\text { with "disruptive" and } \\
\text { "unpredictable" rotas imposed. } \\
\text { - One respondent had already } \\
\text { "delayed starting a family until I } \\
\text { have a more settled lifestyle [than } \\
\text { training allows]," fearing the ability } \\
\text { to now do so with the proposed } \\
\text { conditions. }\end{array}$ \\
\hline
\end{tabular}




\begin{tabular}{|c|c|c|c|}
\hline $\begin{array}{l}\text { Stifling of Innovation } \\
\text { and Excellence }\end{array}$ & $\begin{array}{l}\text { - "Claustrophobic" nature of } \\
\text { contract predicted to "dampen } \\
\text { any aspiration to better improve } \\
\text { the [clinical] service." } \\
\text { "Limit[ing] of the highest } \\
\text { performing employees with } \\
\text { huge ambition and drive," } \\
\text { likened to "putting a speed limit } \\
\text { of } 100 \mathrm{~km} \text { per hour on an } \\
\text { Formula } 1 \text { track." }\end{array}$ & Gender Disparity & $\begin{array}{l}\text { - Female doctors expected to be } \\
\text { "disproportionately } \\
\text { disadvantaged," by a contract } \\
\text { seen to "represent further barriers } \\
\text { to women in medicine," due to its } \\
\text { "family unfriendly" nature. } \\
\text { - Inability to ever "change the } \\
\text { contract" interpreted as } \\
\text { prohibition of temporary switch } \\
\text { "to part-time work" if required in } \\
\text { the future. } \\
\text { - Seen as "discriminatory," and even } \\
\text { "misogynistic." }\end{array}$ \\
\hline Inequity & $\begin{array}{l}\text { - "Completely and utterly unfair" } \\
\text { disparity versus existing } \\
\text { contracts. } \\
\text { - Augmentation of an already } \\
\text { "tiered consultancy" system } \\
\text { anticipated to "create division" } \\
\text { and lead to "hostile working } \\
\text { conditions," with a "potential } \\
\text { fall-out and negative impact for } \\
\text { patients and services." }\end{array}$ & Doctor Wellbeing & $\begin{array}{l}\text { - Potential impact of contract on } \\
\text { doctors' "personal and } \\
\text { professional life" seen as } \\
\text { "untenable for mental health" and } \\
\text { "well-being," risking "increasing } \\
\text { levels" of "already high" doctor } \\
\text { "burnout." }\end{array}$ \\
\hline Autonomy & $\begin{array}{l}\text { - An "overall degradation of } \\
\text { service autonomy" was feared, } \\
\text { with consequent } \\
\text { "disengagement [of } \\
\text { consultants]...from advocacy for } \\
\text { their clinical service," predicted. } \\
\text { - Outside the workplace, } \\
\text { respondents questioned the } \\
\text { employer's proposed } \\
\text { "jurisdiction over every aspects } \\
\text { of doctors lives," perceiving "a } \\
\text { contract of ownership," with } \\
\text { doctors becoming "the puppets } \\
\text { of the HSE." }\end{array}$ & $\begin{array}{l}\text { Sacrifices \& } \\
\text { Skillset }\end{array}$ & $\begin{array}{l}\text { - Respondents outlined high-level } \\
\text { skillsets and qualifications } \\
\text { obtained at "great personal } \\
\text { sacrifice," during "gruelling years } \\
\text { of training" and "service } \\
\text { provision," and overseas } \\
\text { fellowships, honing "essential } \\
\text { skills" that may not be "currently } \\
\text { provided in the Irish system." } \\
\text { - Such journeys were undertaken } \\
\text { with the intention of delivering a } \\
\text { level of "a service/care" perceived } \\
\text { as "impossible" within the confines } \\
\text { of the proposed contract. }\end{array}$ \\
\hline $\begin{array}{c}\text { Unilaterality of } \\
\text { Proposal }\end{array}$ & $\begin{array}{l}\text { - The "unilateral" nature of the } \\
\text { proposed contract, believed to } \\
\text { have been "drafted" with "no } \\
\text { engagement" or "meaningful } \\
\text { interaction" with the relevant } \\
\text { representative bodies nor "those } \\
\text { who would be expected to sign } \\
\text { it," was seen as "a major } \\
\text { concern," and as an "absolute } \\
\text { power grab [by the employer]." }\end{array}$ & $\begin{array}{l}\text { Future Inflexibility } \\
\text { of Contract }\end{array}$ & $\begin{array}{l}\text { - Apparent inability of a contracted } \\
\text { consultant to "ever" "change } \\
\text { contract type in the future," seen as } \\
\text { diametrically opposed to the } \\
\text { flexibility expected by the employer, } \\
\text { with a "seemingly open ended } \\
\text { commitment to adhere to literally } \\
\text { any policy [the employer] should } \\
\text { introduce" being demanded. }\end{array}$ \\
\hline $\begin{array}{l}\text { Lack of Clarity } \\
\text { Regarding } \\
\text { Remuneration }\end{array}$ & $\begin{array}{l}\text { - The lack of clarity and } \\
\text { transparency regarding } \\
\text { remuneration, with "no actual } \\
\text { salary listed in the contract," was } \\
\text { expressed as concerning. }\end{array}$ & Degradation & $\begin{array}{l}\text { - The "tone of [the] contract" was } \\
\text { interpreted to "treat consultants as } \\
\text { staff to be curtailed and controlled, } \\
\text { rather than team leaders trusted to } \\
\text { provide care, educate and instigate } \\
\text { positive change." }\end{array}$ \\
\hline
\end{tabular}




\begin{tabular}{|c|c|c|c|}
\hline & & & $\begin{array}{l}\text { - Perceived "attempts to } \\
\text { commoditise healthcare," and to } \\
\text { "deprofessionalise physicians," } \\
\text { were seen as inconsistent with "an } \\
\text { unbiased vision for patient care." }\end{array}$ \\
\hline Draconian Nature & $\begin{array}{l}\text { - The contract was described as } \\
\text { "Draconian," "dictatorial," } \\
\text { "totalitarian," "exploitative," and } \\
\text { as "creat[ing] a toxic power } \\
\text { dynamic," whilst adopting a } \\
\text { "tone...of indentured servitude," } \\
\text { and "reflect[ing] the adversarial } \\
\text { nature of the [Department of } \\
\text { Health] towards consultants." }\end{array}$ & Demoralisation & $\begin{array}{l}\text { - The contract was viewed as "highly } \\
\text { disheartening." } \\
\text { - Respondents described the } \\
\text { document "ruin[ing] my desire to } \\
\text { practice medicine in Ireland," and } \\
\text { at "12 years after gradaution," } \\
\text { "question[ing] strongly whether } \\
\text { any of it was worth it." }\end{array}$ \\
\hline $\begin{array}{l}\text { Vilification of } \\
\text { Profession }\end{array}$ & $\begin{array}{l}\text { - The contract was seen to } \\
\text { "consolidate the Irish } \\
\text { government (and media's) } \\
\text { approach" to treating doctors "as } \\
\text { villains with inherently bad } \\
\text { intentions;" perceived as "a } \\
\text { scapegoating tactic." } \\
\text { - The commitment to "patient } \\
\text { care" of "doctors around this } \\
\text { country," who "go above and } \\
\text { beyond } 365 \text { days a year, making } \\
\text { personal sacrifices, } \\
\text { compensate for... [health service] } \\
\text { ineptitude with appalling } \\
\text { logistical, structural and fiscal } \\
\text { failures," was stressed. } \\
\text { "Manipulative marketing" of the } \\
\text { contract, with financial sums that } \\
\text { are "not stated" in the contract } \\
\text { being "bandied around...in the } \\
\text { media," was seen as } \\
\text { "underhanded," with a "likely } \\
\text { desired effect" of "eroding public } \\
\text { [opinion of] doctors." }\end{array}$ & $\begin{array}{c}\text { Sadness \& } \\
\text { Betrayal }\end{array}$ & $\begin{array}{l}\text { - The contract's "demoralizing" terms } \\
\text { were described as "devastating" and } \\
\text { as a "kick in the teeth" by the } \\
\text { Department of Health. } \\
\text { - Emphasised in the context of a } \\
\text { recent "unprecedented global } \\
\text { pandemic" and "cyber-attack," } \\
\text { demanding extraordinary efforts } \\
\text { from healthcare workers. } \\
\text { - Impression of Department of Health } \\
\text { hypocrisy - with "all this talk of } \\
\text { frontline workers and praise for } \\
\text { doctors...promoted on the media," } \\
\text { juxtaposed against the belief that } \\
\text { "when it comes down to it, the } \\
\text { [public health service] treats its } \\
\text { physicians like dirt." }\end{array}$ \\
\hline $\begin{array}{c}\text { Emigration / } \\
\text { Alternative Practice }\end{array}$ & $\begin{array}{l}\text { - Respondents were prompted by } \\
\text { the proposed contract to } \\
\text { consider options outside of Irish } \\
\text { public healthcare, including the } \\
\text { "devastating" option of "leaving } \\
\text { a medical career altogether," and } \\
\text { exclusive private practice despite } \\
\text { having "never previously } \\
\text { considered," the latter. } \\
\text { Emigration was the most } \\
\text { frequently considered option - } \\
\text { discussed with regret and } \\
\text { sadness, with descriptions of } \\
\text { doctors "resigning" themselves } \\
\text { to "leave on fellowship" and "not } \\
\text { return," despite having "always } \\
\text { wanted to return home" and }\end{array}$ & $\begin{array}{c}\text { Obstetric-Specific } \\
\text { Concerns }\end{array}$ & $\begin{array}{l}\text { - Specific ramifications for obstetric } \\
\text { - In the absence of a private } \\
\text { obstetric hospital within Ireland, it } \\
\text { was noted that "private obstetric } \\
\text { practice in Ireland will be } \\
\text { monopolised" by a limited pool of } \\
\text { consultants practicing on } \\
\text { current/old contracts. The initial } \\
\text { consequences of "reduced } \\
\text { choice" for patients and } \\
\text { potentially "more expensive fees," } \\
\text { were outlined, with subsequent } \\
\text { abolition of private obstetric care } \\
\text { "once the current combined- } \\
\text { contract consultants retire." }\end{array}$ \\
\hline
\end{tabular}




\begin{tabular}{|c|c|c|c|}
\hline $\begin{array}{l}\text { Emigration / } \\
\text { Alternative Practice }\end{array}$ & $\begin{array}{l}\text { "treat patients attending Irish } \\
\text { [hospitals]." } \\
\text { - Several respondents described } \\
\text { being "headhunted" for jobs } \\
\text { abroad or "begged to stay" in } \\
\text { fellowship institutions, whilst } \\
\text { being offered far preferable } \\
\text { working conditions with "stability } \\
\text { and autonomy" and facilitated in } \\
\text { "fulfilment of career goals." }\end{array}$ & $\begin{array}{l}\text { Obstetric-Specific } \\
\text { Concerns }\end{array}$ & $\begin{array}{l}\text { - Seen as incongruent with the } \\
\text { National Women and Infants } \\
\text { Health Programme's commitment } \\
\text { to a "woman's choice" in } \\
\text { pregnancy (HSE, 2017). }\end{array}$ \\
\hline $\begin{array}{l}\text { Concern that } \\
\text { Patients will Suffer }\end{array}$ & $\begin{array}{l}\text { - Likelihood of the contract } \\
\text { "driv[ing] newly-qualified Irish } \\
\text { consultants away," and the } \\
\text { potential for "deskilling" of } \\
\text { procedural specialists and } \\
\text { impeded training "of subsequent } \\
\text { generations" highlighted. } \\
\text { - Potential "establish[ment] of an } \\
\text { inequitable, true "two-tier" } \\
\text { health system," was perceived, } \\
\text { with 'public' and 'private' } \\
\text { patients having access to entirely } \\
\text { separate sets of doctors. } \\
\text { - A bleak vision of "complex care } \\
\text { shift[ing] towards private } \\
\text { hospitals," with consequent } \\
\text { rising insurance costs for } \\
\text { "ordinary families," culminating } \\
\text { in greater demand on public } \\
\text { hospitals, which would be unable } \\
\text { to "withstand the surge and } \\
\text { impact," was portrayed. } \\
\text { - Fear expressed that this contract } \\
\text { "will demolish any hope of for } \\
\text { redemption of the Public } \\
\text { Hospital Service for generations } \\
\text { to come," posing a monumental } \\
\text { "disservice to patients." } \\
\text { - These concerns expressed in } \\
\text { addition to advocacy concerns } \\
\text { above. }\end{array}$ & $\begin{array}{c}\text { Fear of a } \\
\text { Workforce Crisis }\end{array}$ & $\begin{array}{l}\text { - A workforce crisis was predicted } \\
\text { should the proposed Sláintecare } \\
\text { contract be imposed. } \\
\text { - Some specialities were viewed as } \\
\text { "already at crisis point," and one } \\
\text { respondent reported } \\
\text { conversations with colleagues } \\
\text { making "it...abundantly clear that } \\
\text { new entrant consultants will not } \\
\text { access this contract." } \\
\text { Repeated concerns raised that the } \\
\text { Sláintecare contract would } \\
\text { "precipitate a complete crisis } \\
\text { within the HSE in terms of } \\
\text { recruitment and service } \\
\text { provision." - Viewed as a situation that would } \\
\text { "hasten the demise of public } \\
\text { healthcare in Ireland," and "would } \\
\text { not be remediable for decades." }\end{array}$ \\
\hline
\end{tabular}

Further themes raised by a smaller number of respondents and not discussed in detail for brevity included a willingness to consider public-only practice within the context of a 'workable' contract, inadequacy of the current Health Service Executive infrastructure to facilitate efficiency within the terms of the contract, concerns regarding grievance processes and stipulations regarding 'owing' the employer sick pay, further concerns regarding training and work-life balance, the retirement age of 70 years, the lack of provision of travel expenses and the potential impact on consultants' job satisfaction and fulfilment.

\section{Discussion}

A very high number of responses $(n=1109)$ to the survey were received over a short ( 5 day) time period, suggesting that respondents had strong feelings and viewed the proposed contract as an important topic of discussion. A number of key professional and personal concerns relating to the terms of the proposed Sláintecare contract were identified by a specialist trainee population that would be expected to accept consultant positions over the coming months and years. 
The Irish Medical Council's Guide to Professional Conduct and Ethics identifies patient advocacy as an integral component of professionalism: stating that medical practitioners should "speak on behalf of individual patients, to help make sure they receive appropriate healthcare," and "support all patients by promoting the fair distribution of limited resources and fair access to care" (Irish Medical Council, 2019; Chapter 2, Section 4.5). Survey respondents were concerned that the contract's stipulations regarding the pathways via which "patient advocacy" "should take place" and apparent constraints on "information given to the public" created a potential conflict with professional obligations.

Skill-decay is a well-recognised concept in human performance analysis, with mastered skills shown to decline with increasing non-practice interval (Arthur, 1998). Therefore, it is perhaps unsurprising that for a diverse array of surgical procedures, highvolume surgeons and high-volume hospitals are thought to produce superior patient outcomes (Morche, Mathes, \& Pieper, 2016). Over $50 \%$ of survey respondents were concerned about deskilling in their specialist field should full-time, public-only contracts be imposed, due to current and anticipated procedural access and inadequate resources, beds, capacity and infrastructure. This is the context of an already over-stretched public healthcare system, with waiting lists approaching 1 million patients (Irish Hospital Consultants' Association, 2020). Whilst trainees may be unopposed to public-only work within public hospitals, the significant lack of appetite for the contract likely stems in part from the prohibition of a doctor also providing patient care in the private sector, over and above public commitments.

Ireland is currently considered a world leader in scientific research capability (Nature, 2021). The Irish Research Council's (IRC) Strategic Plan 2020-2024 states an aim to "leverag[e] the skills, knowledge and talent of excellent researchers to harness maximum benefit," referring to a "researcher-centred approach," and stating "a strong commitment to collaboration and partnership with national and international stakeholders" (Irish Research Council, 2020). Survey respondents repeatedly expressed concern that the future of Irish academic medicine was threatened by the proposed contract's terms, thereby suggesting it would be incompatible with this stated national vision for research and innovation.

Trainees were concerned about the impact of the proposed contract on working patterns and on personal and family life. These survey responses were received less than a month after the Irish Medical Council (IMC) launched its 'Doctor Wellbeing' campaign in response to concerns regarding the same and acknowledge the essential role of doctor well-being in optimal patient care and safety (Irish Medical Council, 2021). Trainees' concerns regarding the proposed contract's potential impact on their lives and wellbeing may be viewed starkly against this background.

The results of this study highlight the potential of the Sláintecare contract to have a profoundly negative impact on the Health Service Executive (HSE) workforce. Fewer than 1\% of survey respondents expressed a preference to work exclusively in private practice prior to reading the contract. However, $84.7 \%$ of respondents described themselves as willing to consider a private-only contract having become acquainted with the proposed public contract's terms. Ireland is already "losing almost as many doctors to emigration as it trains each year" (Humphries, 2017), and relies on a greater number of international medical graduates to staff its hospitals than any other European country (OECD, 2019). The proposed contract's terms have been interpreted as a greater disincentive to practice within Ireland. The vast majority of the study cohort (93.7\%) stated that they would consider working abroad instead of in Ireland as a result of the proposed contract. This may have major implications for the future of workforce planning and departmental staffing.

\section{Conclusion}

This study highlights the perceptions of Irish-trained higher specialist trainees and fellows of the proposed Sláintecare consultant contract. Multiple grave concerns surround both personal and professional aspects of the contract's terms. With a pre-existing consultant shortage, in which approximately 700 posts remain unfilled on a permanent basis (Health Service Executive, 2020), these results emphasise the necessity for a collaborative, negotiable process to create a consultant contract that would be attractive. Almost all respondents have stated they may emigrate rather than accept the current conditions, which will have catastrophic implications for training, service provision and workforce planning. The aim of the Sláintecare contract is to attract and train the very best clinicians. However, the currently proposed contract seems highly unlikely to retain these very clinicians.

\footnotetext{
Abbreviations

DoH - Department of Health

HSE - Health Service Executive of Ireland

NCHD - Non-Consultant Hospital Doctor
}

CCT / CCST - Certificate of Completion of Training / Certificate of Completion of Surgical Training 
$\mathrm{SpR}-$ Specialist Registrar

\section{References}

[1] Arthur, W., Jr., Bennett, W., Jr., Stanush, P. L., \& McNelly, T. L. (1998). Factors that influence skill decay and retention: A quantitative review and analysis Human Performance, 11(1), 57 101. doi:10.1207/s15327043hup1101_3

[2] Department of Health. (2021a). Government approves Sláintecare Implementation Strategy and Action Plan 2021-23. Department of Health. In: Government of Ireland.Retrieved from https://www.gov.ie/en/press-release/eb9df-government-approves-slaintecareimplementation-strategy-and-action-plan-2021-23-with-funding-of-3-6-9bn-over-3-years/

[3] Department of Health. (2021b). Sláintecare Contract as of 31 May 2021. Department of Health. In: Irish Medical Organisation.Retrieved from https://www.imo.ie/i-am-a/consultant/latest-news/slaintecare-contract/Draft-Slaintecare-Contract.pdf

[4] Health Service Executive, H. S. E. (2017). National Women and Infants Health Programme In.Retrieved from https://www.hse.ie/eng/about/who/acute-hospitals-division/woman-infants

[5] Health Service Executive, H. S. E. (2020). HSE National Doctors Training and Planning. In.Retrieved from https://www.ihca.ie/_fileupload/NDTP\%20response\%20to\%20lHCA\%20on\%20Consultant\%20Establishment\%20\%20Vacancies\%20and\%20tenures\%20Nov\%202020(1).pdf

[6] Health Service Executive, H. S. E. (2021). Medical Workforce Report 2020-2021 In: Health Service Executive of Ireland.Retrieved from https://www.hse.ie/eng/staff/leadership-education-development/met/ed/rep/medical-workforce-report-2020-21.pdf.

[7] Humphries, N., Creese, J., Byrne, J. P., \& Connell, J. (2021). COVID-19 and doctor emigration: the case of Ireland. Hum Resour Health, 19(1), 29. doi:10.1186/s12960-021-00573-4

[8] Humphries, N. (2017). The hospital doctor retention and motivation project. In: Health Research Board Awards.Retrieved from https://www.hrb.ie/funding/funding-awarded/awards-made/award/the-hospital-doctor-retention-and-motivation-hdrm-project

[9] Irish Hospital Consultants' Association, I. H. C. A. (2020) NTPF waiting lists could reach 1 million as latest figures show an additional 11,844 people added in May. In.Retrieved from https://www.ihca.ie/news-and-publications/ntpf-waiting-lists-could-reach-1-million-as-latestfigures-show-an-additional-11844-people-added-in-may

[10] Irish Medical Council (IMC) (2019). Guide to Professional Conduct and Ethics for Registered Medical Practitioners (Amended). In (8th Edition ed.).Retrieved from https://www.medicalcouncil.ie/news-and-publications/reports/guide-to-professional-conduct-and-ethics-forregistered-medical-practitioners-amended-.pdf

[11] Irish Medical Council IMC. (2021). Doctor wellbeing a key patient concern warns council. In: The Medical Independent.Retrieved from https://www.medicalindependent.ie/doctor-wellbeing-a-key-patient-safety-concern-warns-council/

[12] Irish Research Council, I. R. C. (2020). Strategic Plan 2020-2024. Retrieved from https://research.ie/assets/uploads/2020/01//rish-ResearchCouncil-Strategic-Plan-2020-2024.pdf

[13] Morche, J., Mathes, T., \& Pieper, D. (2016). Relationship between surgeon volume and outcomes: a systematic review of systematic reviews. Syst Rev, 5(1), 204. doi:10.1186/s13643-016-0376-4

[14] Nature, Nature Indices (2021). Country/Territory Outputs. In: Nature.Retrieved from https://www.natureindex.com/country-outputs/Ireland

[15] Organisation for Economic Co-operation and Development (OECD) (2019). Recent trends in international migration of doctors, nurses and medical students. In. Paris: OECD Publishing.Retrieved from https://www.oecd.org/health/recent-trends-in-international-migration-ofdoctors-nurses-and-medical-students-5571ef48-en.htm

[16] Organisation for Economic Co-operation and Development (OECD) (2019). OECD/European Observatory on Health Systems and Policies. Ireland: country health profile 2019, state of health in the EU. . In. Brussels: OECD Publishing, Paris/European Observatory on Health Systems and Policies

Appendices are available upon request. 